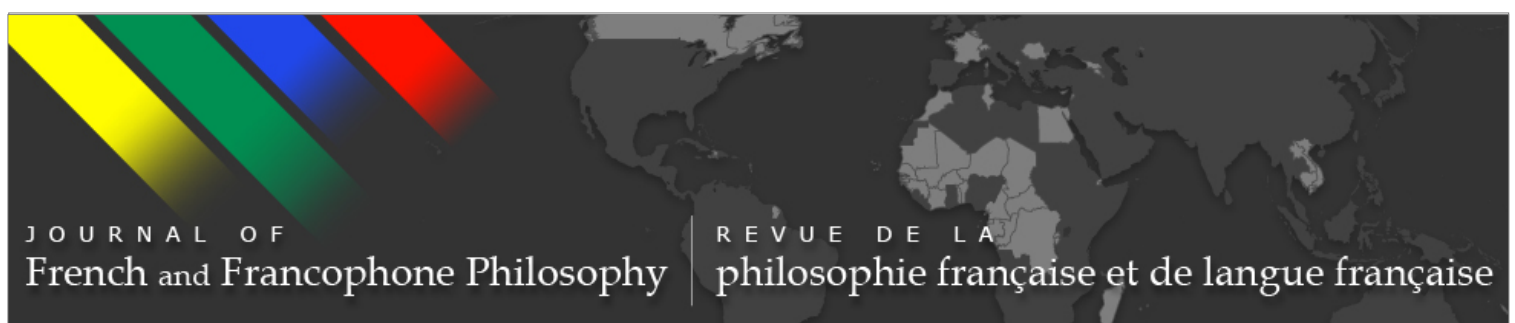

\title{
Husserl and Ricoeur
}

The Influence of Phenomenology on the Formation of Ricoeur's Hermeneutics of the 'Capable Human'

\section{Dermot Moran}

Journal of French and Francophone Philosophy - Revue de la philosophie française et de langue française, Vol XXV, No 1 (2017) pp 182-199.

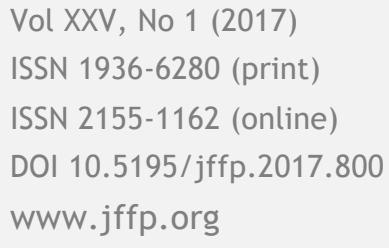

\section{(c) EY-NC-ND}

This work is licensed under a Creative Commons Attribution-Noncommercial-No Derivative Works 3.0 United States License.

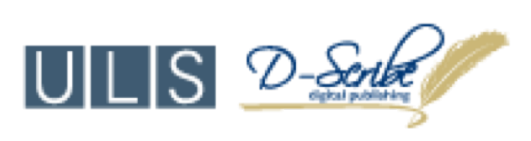

This journal is operated by the University Library System of the University of Pittsburgh as part of its D-Scribe Digital Publishing Program, and is co-sponsored by the University of Pittsburgh Press 


\title{
Husserl and Ricoeur
}

\section{The Influence of Phenomenology on the Formation of Ricoeur's Hermeneutics of the 'Capable Human'}

\author{
Dermot Moran \\ University College Dublin \& Wuhan University
}

The phenomenology of Edmund Husserl had a permanent and profound impact on the philosophical formation of Paul Ricoeur. One could truly say, paraphrasing Maurice Merleau-Ponty's brilliant 1959 essay "The Philosopher and his Shadow," ${ }_{1}$ that Husserl is the philosopher in whose shadow Ricoeur, like Merleau-Ponty, also stands, the thinker to whom he constantly returns. Husserl is Ricoeur's philosopher of reflection, par excellence. Indeed, Ricoeur always invokes Husserl when he is discussing a paradigmatic instance of contemporary philosophy of "reflection" and also of descriptive, "eidetic" phenomenology. Indeed, I shall argue in this chapter that Husserl's influence on Ricoeur was decisive and provided a methodology which is permanently in play, even when it has to be concretized and mediated by hermeneutics, as Ricoeur proposes after 1960. Of course, Ricoeur never met Husserl, who died in 1938, personally. He was only sixteen years of age when Husserl gave his famous lectures in Paris in 1929, but Ricoeur was life-long friends with Husserl's former student, Eugen Fink (1905-1970), and with Fr. Herman Leo Van Breda (1911-1974), ${ }^{\text {s }}$ who had been active, with Fink and Malvine Husserl, in saving the Husserl Nachlass and establishing the Husserl Archives in Leuven in 1939.

Ricoeur himself has frequently acknowledged that Husserl and Gabriel Marcel were his first real philosophical mentors." Ricoeur had met Marcel already earlier on in 1934, when he was studying at the Sorbonne for his aggregation. The young Ricoeur attended several of Marcel's soirées at his home. They continued to correspond, especially while Ricoeur was in the prisoner-of-war camp in Germany. Marcel was the first person Ricoeur visited after the war, and there were in contact until Marcel's death. Nevertheless, Ricoeur records that he drew away from Marcel's philosophy precisely because of its absence of "conceptual structure." ${ }_{\text {s }}$ It was Husserl who provided this conceptual structure for Ricoeur's philosophy.

Journal of French and Francophone Philosophy | Revue de la philosophie française et de langue française Vol XXV, No 1 (2017) | www.jffp.org | DOI 10.5195/jffp.2017.800 
Maurice Merleau-Ponty was also a long-term friend and colleague of Ricoeur's, and together they were involved in informal reading groups of Husserl's philosophy and in the founding and running of the Husserl Archives in Paris until Merleau-Ponty's sudden death in 1961. Ricoeur was one of a small group of philosophers - along with Sartre and Merleau-Ponty - who were reading Husserl in France in the late 1930s, until the outbreak of the Second World War disrupted their activities. Ricoeur's Husserl is the Husserl who entered into France through the work of Eugen Fink, Gaston Berger, Emmanuel Levinas, and Merleau-Ponty. The sole available primary text in French was the Méditations Cartésiennes, ${ }^{6}$ published in 1931, along with a special issue of the Revue Internationale de Philosophie which appeared in 1939 to mark the death of Husserl and which contained The Origin of Geometry fragment, ${ }^{7}$ that later was included in Walter Biemel's edition of Husserl's Crisis of European Sciences in 1954. ${ }^{.}$Another important source was Levinas' 1930 study of Husserl's intuitionism.'

Until he began to present himself primarily as a hermeneuticist and, then, as a philosopher of language, around 1960, Ricoeur situated himself squarely in the tradition of French (Husserlian) phenomenology, with its existential orientation towards humanism and freedom, although he was from the start critical of Jean-Paul Sartre's account of freedom in particular and kept himself at a distance from Sartre's work generally. Heidegger's presence in Ricoeur's work (largely through the influence of Jean Beaufret) is much more ambiguous and would require a separate study. ${ }^{10}$ Both Sartre and Merleau-Ponty were deeply interested in Husserl's conception of intentionality and in particular offered novel phenomenological accounts imagination (Sartre)" and perception (Merleau-Ponty). Ricoeur initially came to Husserl from a somewhat different angle, namely the existentialism of Marcel and Jaspers, but he went on to embrace and extend descriptive phenomenology primarily to cover the domain of voluntary action and human praxis informed by an ethical sensitivity.

According to this French tradition, Ricoeur puts Husserl in confrontation with Levinas, Freud, Heidegger, and others - but Ricoeur always felt the need to go back and situate his own thinking on some particular issue with regard to Husserl. Husserl is his "point de repère" and even Kant is understood in relation to Husserl,,$^{12}$ and Ricoeur believes Husserl diagnoses an "implicit phenomenology behind the Kantian epistemology." ${ }_{13}$ Especially in the 1940s and 1950s, Ricoeur carried out an intensive study of Husserl's texts, not just Ideas I and Cartesian Meditations, but also Ideas II," when it appeared in the Husserliana edition in 1952, and which Ricoeur immediately reviewed in detail..$^{\text {s }}$

Ricoeur discusses Husserl in all his major books up until 1960, when he moves on from his methodology of reflection and begins his hermeneutic explorations of symbol and myth ${ }^{16}$ and then again explicitly in later texts in the nineteen eighties such as Time and Narrative (especially Volume Three). ${ }^{17}$

Journal of French and Francophone Philosophy | Revue de la philosophie française et de langue française 
In his early works, Ricoeur offered penetrating phenomenological, "eidetic" descriptions of the nature of the will, of human voluntary action and motivation, habit, and the involuntary, the nature of imagination and symbolism, even expanding his horizon to conceptualizing the experience of evil and the unconscious. He addresses all the central aspects of Husserl's phenomenology, from the commitment to the science of essential truths founded in intuition, the project of determining the "significance of significance," the genesis of meaning, the true nature of the epoche and the reduction, the critique of Cartesian intellectualism, the nature of the transcendental ego, the problem of the constitution of the other, and Husserl's problematic conception of the life-world. Later he will return to the importance of the "hyletic phenomenology" of inner time consciousness, in Volume Three of Time and Narrative, as well as discussing Husserl's egology in Oneself as Another.

Ricoeur himself had originally studied at the University of Rennes with Roland Dalbiez (1893-1976), a Catholic and a close friend of Jacques Maritain, who was one of the first to introduce Sigmund Freud into France, and who placed psychoanalysis in dialogue with then contemporary Thomism. ${ }^{18}$ One can see the influence of Dalbiez in Ricoeur's 1965 analysis of Freud, Freud and Philosophy, ${ }^{19}$ but, in regard to an exposure to Husserl, Ricoeur was more or less an autodidact. Ricoeur's initial licence ès lettres from Rennes was primarily a teaching qualification. Ricoeur unfortunately failed the entry examination for the École Normale Supérieure and then entered the Sorbonne in 1934 to study for the agrégation examination which he obtained in 1935 . He then did his year of military service and began teaching in a lycée at Lorient.

At the outbreak of the Second World War in 1939, Ricoeur enlisted in the army and was reputedly a good soldier, but he was captured on 7 June $1940 . .^{20} \mathrm{He}$ was sent to a prisoner of war camp in Germany, where he occupied himself with his intensive reading, translation and commentary on Husserl's Ideas, which he eventually obtained in 1943. ${ }^{21}$ While in captivity at the Oflag II-B camp in Pomerania, during the War until 1945, Ricoeur began secretly to translate Husserl's Ideas I into French, and this translation was eventually published in 1950.2 In the camp, he also began an annotation of Ideas I, written clandestinely, and also published in 1950. Imprisoned with Ricoeur were other intellectuals, including another philosopher Mikel Dufrenne (1910-1995), with whom Ricoeur later co-authored a book on Jaspers. ${ }^{23}$ In the prison camp, Ricoeur had access to some books, through the Red Cross and read in particular Karl Jaspers but he also had a copy of Husserl Ideas which he laboriously translated and on which he commented (writing in a miniscule hand in the margins of the text). ${ }_{24}$ Ricoeur's translation and commentary on Ideas I later became the minor thesis for his doctorat-ès-lettres at the Sorbonne, ${ }^{25}$ while his major thesis was his Philosophie de la volonté. Tome I: Le volontaire et l'involontaire (Freedom and Nature: The

Journal of French and Francophone Philosophy | Revue de la philosophie française et de langue française Vol XXV, No 1 (2017) | http://www.jffp.org | DOI 10.5195/jffp.2017.800 
Voluntary and the Involuntary). ${ }^{26}$ Ricoeur's doctoral degree was awarded on April 29, 1950. In the meantime, Ricoeur had taken up a lecturer position at the University of Strasbourg from 1948 until 1956, when he was appointed to a chair at the Sorbonne.

The 1950s was Ricoeur's phenomenological decade, inaugurated by his translation and commentary on Husserl's Ideas (1950) and also by his groundbreaking phenomenological study of the will, published as Volume One of his Philosophy of the Will: The Voluntary and the Involuntary. Ricoeur also published a series of essays on phenomenology which were later collected as A l'école de la phénoménologie. ${ }^{28}$ After the War, Ricoeur was active with Gaston Berger, Merleau-Ponty, Jean Wahl, and others, in establishing of the Husserl Archives in Paris. Indeed, shortly after the war ended, in January 1947, Ricoeur visited the Husserl Archives in Leuven, Belgium. ${ }^{2}$ Ricoeur took copies of Husserl's manuscripts, which Van Breda had given him, to Strasbourg. ${ }^{30}$ Riceour would soon begin lecturing at the University of Strasbourg, where he replaced Jean Hyppolyte (1907-1968), who had moved to the Sorbonne. Merleau-Ponty, Ricoeur, and others, had already been sharing Husserl's unpublished manuscripts provided by Van Breda. Already in 1942, during the war, Van Breda would make occasional trips to Paris by train, and secretly provide Jean Cavaillès and his circle with copies of Husserl's manuscripts, which they eagerly discussed. Eventually, in 1957, the Husserl Archives in Paris was officially opened - with Gaston Berger, Paul Ricoeur, Jean Wahl, Jean Hyppolite and Merleau-Ponty, among the founders. Indeed, Ricoeur took over as director of the Paris Husserl Archives in 1961, following the sudden death of Merleau-Ponty.

In the fifties Ricoeur saw himself initially primarily as a phenomenologist and his early works were phenomenological eidetic studies of themes such as the nature of the will which is approached through the reduction. Ricoeur moved in the circles of Husserlian phenomenology. In 1951, for instance, he participated in the Brussels conference on the current state of phenomenology with Merleau-Ponty and Fink where he presented his paper on "Methods and Tasks of a Phenomenology of the Will." ${ }^{31}$ In an interview with Charles Reagan, Ricoeur recalled that he began "with a reflexive method borrowed from Husserl, with a certain existential influence similar to that of Merleau-Ponty." ${ }_{32}$ The aim was to arrive at the "principal structures of mental life." His original problem was the phenomenological project of identifying the essential structure of the will and of voluntary action, as part of an overall anthropology of what he came to call "the capable human" (l'homme capable). ${ }^{33}$ It is difficult to overemphasize the importance of Husserl's Ideas I in Ricoeur's overall conception of method in Freedom and Nature. He cites Husserl's comment that the will needed to be approached in terms of the noetic-noematic structure of intentionality. Ricoeur's intensive reading of a single book of Husserl contributes to a particular conception of phenomenology as a

Journal of French and Francophone Philosophy | Revue de la philosophie française et de langue française 
method. It is a method of reflection, grounded in intuition, but -through the epoché and reduction-abstracted from all actuality and contemplating essences in their pure ideality. Ricoeur wants an eidetics of the will but in the end he also wants to advance to a new ontology of the will. He is somewhat suspicious of phenomenologists moving too quickly to the existential features of the life-world (as exemplified in Husserl's Crisis). Ricoeur believes one must remain longer with the noetic-noematic intentional structures in order to achieve clarity. As he proclaims: "In the early stages at least, phenomenology must be structural." "*icoeur is also critical of aspects of Husserl's approach. Perhaps most crucially, he rejects Husserl's classification of willing (along with memory, imagination, etc.) as a form of "representation" (Vergegenwärtigung). This characterization, he believes, is simply a Husserlian prejudice. ${ }^{s}$

Gradually, especially as Ricoeur began to appreciate the religious texts that discussed willing (including Augustine), issues of expressive, metaphorical language and symbolism came to the fore - and, thus, the need for a hermeneutic perspective-especially when he began to contemplate the issue of evil and of the bad will. Indeed, psychoanalysis also began to insist itself at this point, also because of the problem of the "bad will." As Ricoeur noted: "The break with this method [eidetic phenomenology] came from the recognition of evil as a fundamental structure of the will." ${ }^{\prime}$ As a result of this new approach to evil, L'Homme faillible (1960, Fallible Man) goes beyond the purely phenomenological analyses of evil found in Freedom and Nature and moves in a more existential and symbolic direction, although he still begins from a phenomenological analysis (and indeed an encounter with Kant). This new move towards the hermeneutic interpretation of language and symbolism is complemented by The Symbolism of Evil, which originally appeared as Part Two of The Voluntary and the Involuntary.".

Arising from his work on freedom and the free will, Ricoeur was drawn to a consideration of the nature of evil and especially how the fundamental truths of the human condition are expressed in symbols in the writings of the great religions, in a way that was not immediately conceptualized. This led Ricoeur to realize that phenomenology cannot proceed by concepts alone but had to find a way of explicating the rich meanings embedded in texts, narratives and symbols. But even here there is a Husserlian intonation. Intentionality is already a desire or "will to speak" (vouloir dire) and phenomenology is a logos and especially a desire to name.s. The truth of symbols, Ricoeur proclaims, is truth, in the Husserlian sense, under the epoché - the fulfillment of an intention."s Symbols, for Ricoeur, provoke thinking-- le symbole donne à penser ("the symbol sets us thinking") "w through a kind of double intentionality: the literal, obvious meaning points beyond itself to a deeper meaning. Symbols are inherently dynamic and interwoven in larger narratives; and newly introduced symbols in a culture act to destroy the previously accepted symbols. Symbols left on their own thicken

Journal of French and Francophone Philosophy | Revue de la philosophie française et de langue française

Vol XXV, No 1 (2017) | http://www.jffp.org | DOI 10.5195/jffp.2017.800 
into idolatry, Ricoeur writes. Symbols, on the other hand, give birth to understanding through interpretation. Symbols mediate what cannot be conceptualized directly.

Even after the turn to hermeneutics, phenomenology continues to have a prominent role. In his major 1965 book on Freud, Freud and Philosophy, Ricoeur compares and contrasts Husserl's epoché and reduction to consciousness and Freud's reduction of consciousness (to something deeper)." Ricoeur had been attending Jacques Lacan's seminars from 1960 to 1963,12 and had already been giving papers on the unconscious in connection with his exploration of evil. However, Lacan was reportedly extremely angry with Ricoeur's book on Freud, because it scarcely acknowledged his own work on Freud. One of Lacan's acolytes, J.-P. Valabrega, even wrote a review of Ricoeur's book accusing him of plagiarizing Lacan and Ricoeur was forced to reply. ${ }^{43}$ Even in his analysis of Freud, Ricoeur tries to think of him in relation to Husserl. Indeed, Ricoeur explicitly states that part of the project of Freud and Philosophy is to confront Freud's theories with the resources of Husserl's phenomenology." Thus he contrasts Husserl's epoché to consciousness (which he describes as a kind of "displacement" with Freud's epoché of consciousness. ${ }^{45}$ Ricoeur claims that no reflective philosophy has come as close to Freud's exploration of the unconscious as that of Husserl with his understanding of passivity. Husserl's sedimentation is seen as close to Freud's account of the manner dreams take up symbols that it simply finds in consciousness. ${ }^{46}$ Indeed, Ricoeur describes phenomenology in quite psychoanalytic terms:

Thus phenomenology begins by a humiliation or wounding of the knowledge belonging to immediate consciousness. ${ }^{47}$

But Ricoeur raises questions that push beyond phenomenology, e.g. how far

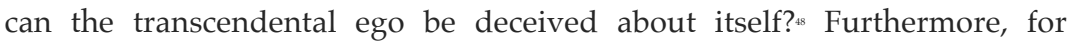
Ricoeur, psychoanalysis is not a reflective discipline in the manner of phenomenology. He writes:

Phenomenology is a reflexive discipline; the methodological displacement it sets into operation is the displacement of reflection with respect to immediate consciousness. ${ }^{*}$

Phenomenology always means, for Ricoeur, certainly from The Voluntary and the Involuntary, but through to his later works, the methodology of extracting essential meanings from lived experiences, as he puts it in his 1975 study, $\mathrm{La}$ Métaphore vive (The Rule of Metaphor).50 Phenomenology is carried out in reflection not in introspection. Thus, in his 1960 study, Fallible Man, , $^{\text {si }}$ Ricoeur stated that he made use of the "method of reflection" and especially employed Husserl's notion of "horizon." ${ }_{52}$ Indeed, Fallible Man begins with a discussion of the phenomenology of perception and the nature of perceptual "excess" as well as givenness in "profiles" (Abschattungen). Looking back on his earlier work, Ricoeur says that already in Fallible Man he took over the

Journal of French and Francophone Philosophy | Revue de la philosophie française et de langue française 
Husserlian concept of perspective borrowed from the phenomenology of perception and applied it to the practical sphere to point to the essential finitude and one-sidedness of our desires, motivations, habits, etc. But then, Ricoeur notes the "transcendence of signification over perception, of speaking over perspective, ${ }^{{ }_{33}}$ which leads him to recognize the importance of interpretation (involving a detour through Aristotle's De Interpretatione). Ricoeur also maintains that Husserlian reflective responsibility (Selbstbeantwortung) is explicitly an ethical enterprise. Making decisions, willing, are forms of taking responsibility, ownership of one's deeds and one's deeds are always part of the world, "inscribed upon the tissue of the world." ${ }_{\text {st }}$

Ricoeur considers phenomenology primarily as a descriptive discipline founded in intuition. He maintains that all phenomenology "takes place on the level of an intuition of an eidos." "There is an intuitionism at the basis of Husserl's philosophy, a point also emphasized by Levinas in his The Theory of Intuition in Husserl's Phenomenology (1930), which was also known to Ricoeur. Already from his early commentary on Ideas I, Ricoeur recognizes that Husserl's groundbreaking conception of the intentionality of consciousness, and its power of going beyond itself, is very close to the existential notion of the transcendence of human existence. ${ }^{56}$ However, Ricoeur also recognizes the importance of the reduction and precisely, given the formulation of Husserl's Ideas, the suspension of "belief in the world." One must "conquer" oneself as a human being in order to apprehend oneself as a pure subject and make visible the noetic-noematic structures of consciousness. ${ }^{57}$ But Ricoeur also notes the inherent egoism within Husserl's philosophy and its failure to fully articulate the other as other since the other is always constituted through analogization and pairing with oneself. ${ }^{. s}$

From the beginning, moreover, Ricoeur was a persistent critic of Husserl's turn to transcendental idealism, which is announced in print in Ideas I but which had been simmering since 1907. According to Ricoeur, Husserl's Cartesian Meditations, which first appeared in French, translated by Emmanuel Levinas and Gabrielle Pfeiffer, and Husserl's 1930 Afterword (Nachwort) to his Ideen, are extreme expressions of this idealism. Ricoeur recognizes that Husserl's Descartes is a Neo-Kantian construct, the cogito is the transcendental ego, ${ }^{59}$ and Husserl completely ignores the role of God as the second certainty in Descartes' system.

Husserl's Freedom and Nature: The Voluntary and the Involuntary published in 1950 (volume one) has a very large phenomenological component, although it is modeled on Karl Jaspers' Philosophy of Existence, which Ricoeur had read in the detention camp. ${ }^{\circ}$ Ricoeur begins from the standpoint of intentionality, which he later interpret as signifying, as "vouloir-dire," wanting to say. Phenomenology is descriptive rather than explanatory. The will is to be given an eidetic analysis. As Ricoeur says: "The axis of the method is a description of the intentional, practical, and

Journal of French and Francophone Philosophy | Revue de la philosophie française et de langue française Vol XXV, No 1 (2017) | http://www.jffp.org | DOI 10.5195/jffp.2017.800 
affective structures of the Cogito in a Husserlian manner." ${ }_{11}$ On the other hand, drawing on Marcel and Jaspers, incarnate existence must be respected as the ultimate mystery. There are aspects of willing and practical life that need to be approached from a different angle, from what he will, at that time, call a "poetics" and "symbolics".

Freedom and Nature accepts the opposition expressed in Merleau-Ponty between scientific objective thought (the view from nowhere) and the perspective of subjectivity. As he puts it, the desire of reflective consciousness is to be total, to be above all perspective and self-sufficient. Reflective consciousness wants to be free of the grip of the passions. Ricoeur believes that Husserl's -and indeed Merleau-Ponty's-- phenomenology had placed too much emphasis on perception, memory and imagination, and other forms of "representative" consciousness and had not sufficiently treated the will and the emotions and affective life generally, which are literally incorporated into the world. What I do is not just something in consciousness, it is an event in the world and not just in my body.

Against Sartre, Ricoeur denies that the experience of freedom is entirely open-ended. In fact, the experience of voluntary movements (e.g. of the body) always involve running up against the involuntary, which includes the unconscious domain, drives, character traits, mechanisms which simply take place in nature (such as recoil, shock, and so on). The voluntary can only take place against the background of the involuntary. Emotions, needs, habits, belong largely to the sphere of the involuntary. The involuntary cannot be apprehended directly since it has no sense until it is taken up by the voluntary: "Only the living interrelationship between the voluntary and the involuntary is intelligible."

In Freedom and Nature, inspired by Husserl, and of course by MerleauPonty, Ricoeur gives a detailed discussion of the "lived body" (Leib) and discusses aspects of Husserl's analysis of 'I can' (Ich kann). The body is a site of movement but also of resistance. The voluntary movement of the body has first to overcome the inertia of nature; one literally has to lift one's body from the ground, to stand upright, to move, is always an overcoming of gravity and resistance. All of this requires willing at a very basic level: "A total absence of willing would be an absence of human being." ${ }_{63}$ Actions are essentially intentional - I do not just move my arm, I engage in a meaningful activity such as writing a letter. There are no decisions without motives ${ }^{6 t}$ and Ricoeur makes use of Husserl's and Pfänder's concept of motivation. Furthermore, Ricoeur adopts Scheler's view that emotions are oriented to values. Human projects are driven by values that are apprehended but not reflected on. To reflect on values is to uncouple their driving force and allow them to be examined in terms of their justificatory character. Ricoeur takes over Husserl's conception of position-taking (Stellungnahme). Once one makes a decision, one is thus-and-so decided. Taking a stand, exercising control, these activities shape the ego.. ${ }^{5}$ Ricoeur carefully distinguishes

Journal of French and Francophone Philosophy | Revue de la philosophie française et de langue française 
between arriving at a decision and the consequent voluntary motion of the body.

Central to Ricoeur's analysis in Freedom and Nature (even in Volume One) is an ontological recognition of human beings as somehow caught in a "dialectic" between the finite and the infinite (Ricoeur's conception of dialectic is influenced both by Ricoeur and also by Jean Hyppolite's studies on Hegel). Already in the Introduction to Freedom and Nature, Ricoeur speaks of a "fault" or "fissure" (faille, écart) at the very heart of the human: freedom (understood in Jasperian terms as transcendence) and the "fault" are the two poles between which human existence oscillates. The fault is not part of the interplay between the voluntary and the involuntary, but is on a completely different level. For Ricoeur, "the fault is absurd"; ${ }^{66}$ and Fallible Man will take up the existential nature of this fault in more detail as a "philosophy of fallibility." ${ }_{67}$

Freedom and Nature also draws on Husserl's analyses of inner timeconsciousness to explicate the manner in which human existence is oriented toward the future. ${ }^{s}$ Time is another area that overlaps between the voluntary and the involuntary. Ricoeur also defends the notion (similar to MerleauPonty) of a practical pre-reflexive self-awareness in action which is the basis for the ego of reflection. ${ }^{\circ}$

Despite the turn to hermeneutics and, indeed, his deep immersion in structuralist and analytic philosophy of language, Ricoeur's fascination with Husserl's phenomenology continues through the sixties and seventies. In an important essay entitled "Phenomenology and Hermeneutics," " a paper presented at the American Philosophical Association in 1975, Riceour addresses what he calls the "destiny" of contemporary phenomenology. He says that what hermeneutics has "ruined" is the idealistic interpretation of phenomenology (as explicated by Husserl himself in the Afterword to his Ideas). There is, he believes, a deeper "mutual belonging" between phenomenology and hermeneutics. Ricoeur critically challenges Husserl's central idealist claims. He was particularly critical of the Cartesian cogito as starting point because for him this immediate beginning was empty unless mediated by language, symbols etc. As he had already stated in Freud and Philosophy:

The first truth -I am I think-remains as abstract and empty as it is invincible, it has to be "mediated" by the ideas, actions, works, institutions, and monuments that objectify it."

Ricoeur also rejects Husserl's assertions concerning the self-founding nature of phenomenology. In his 1975 APA address, he takes issue with a central claim of Ideas, that all transcendence is dubitable (since it proceeds in profiles) and only immanence is indubitable. ${ }^{n 2}$ For Ricoeur, Husserl's pursuit of intentionality was weakened precisely by its conceptuality and by its

Journal of French and Francophone Philosophy | Revue de la philosophie française et de langue française Vol XXV, No 1 (2017) | http://www.jffp.org | DOI 10.5195/jffp.2017.800 
acceptance of perception as the bedrock connection with the world rather than practical, voluntary action which is already normative and engaged.

According to Ricoeur, in this APA address, the first principle of hermeneutics is that, prior to objectivity, there is inclusion: "Belonging-to" (Zugehörigkeit), a Husserlian concept, has to be conceived hermeneutically; it expresses the finitude of knowledge and that all justification rests in a network of other justifications..$^{73}$ All comprehension is mediated by interpretation. Ricoeur, like Gadamer, defends the universality of interpretation. Ricoeur fastened on hermeneutics somewhat after his initial exposure to phenomenology - and hermeneutics come to the fore especially in his 1960 The Symbolism of Evil ${ }^{74}$ and also in Freud and Philosophy (see Riceour's intellectual biography as recounted in the Appendix to Rule of Metaphor). ${ }^{.5}$ This leads Ricoeur, in his mature works after 1960, to propose a new hermeneutical phenomenology or phenomenological hermeneutics influenced by both Heidegger and Gadamer (but also by the emerging French structuralist emphasis on language-but carried out in its own distinctive manner. ${ }^{76}$ Ricoeur's long engagement with the phenomenology of religion also takes on a new dimension after he became friendly with Mircea Eliade, during his visits to the University of Chicago in the 1960s. Ricoeur had first met Eliade in Paris, introduced by Georges Dumézil. Eliade's penetrating and original analyses of basic, universal symbols (informed also by phenomenology) had an enormous influence on Ricoeur.

As Ricoeur's thinking developed, he began more and more to see the dialectical interpenetration, rather than a dichotomy, between description and explanation, and also to see text and action as close in structural form. All understanding requires interpretation and interpretation usually requires mediation and a detour through texts and other forms of sedimented knowledge. As he would put it in The Conflict of Interpretations (Le conflit des interpretations, 1969): "My purpose here is to explore the paths opened to contemporary philosophy by what could be called the graft of the hermeneutical problem onto the phenomenological method" (la greffe $d u$ problème herméneutique sur la méthode phénoménologique). Hermeneutics, for Ricoeur, is centered on the "thing" or "matter" (die Sache) of the text and, therefore, it is not essentially subjectivist. Husserlian phenomenology, on the other hand, practices a "subjectivist hermeneutics". ${ }^{78}$ Ricoeur, accepts with Heidegger and Gadamer, that the project of hermeneutics is the project of self-understanding but self-understanding, for Ricoeur, is an interpretation and proceeds through detours and mediation. Identity is a matter of socially mediated self-definitions. Ricoeur thinks of the subject as always embedded in a social, historical, and linguistic context. His key question is, as Richard Kearney has recalled: "d"ou parlez vous?" - "where are you speaking from?"; "Where are you coming from?". ${ }^{\text {.9 }}$ In this regard, Ricoeur often invokes Heidegger's question in Being and Time: "who is Dasein?" This leads him to question the primacy of subjectivity and, indeed, to reinterpret 
phenomenological intentionality not as self-possession but as openness to otherness.

In his later publications, Ricoeur became particularly focused on Husserl's historical narrative in the Crisis of European Sciences and especially by Husserl's turn to history, which he had already written about in an early 1949 essay, "Husserl and the Sense of History," writing about Crisis manuscripts which would not be published until some five years later in Walter Biemel's Husserliana edition. ${ }^{\text {so }}$ Ricoeur had even contemplated translating the Crisis, but eventually this work was completed by Gérard Granel (1930-2000), who had studied with Maurice Merleau-Ponty and Jean Beaufret.s1 Ricoeur dubbed Husserl one of the "most unhistorical of professors" yet one who was called on by historical events to address the role of history in the formation of culture. ${ }^{.2}$ Thus in his Time and Narrative Volume Ones, Ricoeur invokes Husserl's notion of "questioning back" (Rückfragen) - which he interprets as "genesis of meaning" - as mentioned in Husserl's Crisis of European Sciences. In Volume Two of Time and Narratives, which appeared in French in 1984, Ricoeur also expresses his preference for the long way of "Questioning Back" that Husserl uses in the Crisis. Ricoeur refers to this as "historical intentionality" which he says has its own "noetic intention". Husserl was questioning how Galilean sciences came to dominate Western scientific knowledge and frame the West. Ricoeur is fascinated by the fact that Husserl does offer a narrative in the Crisis - a narrative of the emergence of modern science through the decisive actions of Galileo and others, dividing the subjective-relative properties of the world from the so called "subject-independent" properties. There is already "narrative configuration". Ricoeur thinks Husserl's analysis lays bare what is at the essence of historical consciousness. ${ }^{55}$ Ricoeur wants to resist an easy conflation of history with story-telling (as in fictional narratives). He recognizes the proximity but also the distance between history and story.

Husserl plays a much larger role in Time and Narrative Volume Three, in dealing with the aporetics of time. Husserl is a dominant presence in this volume as Ricoeur discusses Augustine, Kant and Heidegger. Husserl is, for Ricoeur, the philosopher of lived temporality, internal time consciousness, so, in Volume Three, Ricoeur proclaims the need to examine Husserl closely in relation to both Augustine and Kant. Husserl's aim is to make the phenomenon of time appear "by means of an appropriate method," submit the process of time to a direct description. Drawing on Husserl's Lectures on Internal Time Consciousness, objective time, "world time," is excluded in order to focus on inner time, time-consciousness (Zeitbewusstsein). All transcendent presuppositions concerning existents are excluded. In Time and Narrative, Riceour interprets bracketing not as excluding anything but as redirecting the gaze. The apprehension of time is now the primary phenomenon under investigation. Husserl identifies $a$ priori laws that govern the experience of time - it is a two-dimensionsal

Journal of French and Francophone Philosophy | Revue de la philosophie française et de langue française

Vol XXV, No 1 (2017) | http://www.jffp.org | DOI 10.5195/jffp.2017.800 
series with a fixed order, no two different times can ever be conjoined, every time has an earlier and later. The great discoveries of Husserl, for Ricoeur, are retention and protention. Ricoeur discusses Husserl's language and his time diagram in some depth. Husserl examines a sound just as Augustine examined the words of a Latin chanted hymn, deus creator omnium. This sound is, in Husserl's terminology, a peculiar Zeitobjekt. The "now" is not a point but has a transverse or longitudinal intentionality. It has a "durational unity" (Dauereinheit). The present is called a source point (Quellpunkt) because what runs off from it still belongs to it. Ricoeur's analysis of Husserl's account of temporarilty is detailed, careful and insightful. He clearly sees the importance of Husserl's eidetic phenomenology of the experience of temporality but he also recognizes Husserl's larger concerns with the dynamics of culture and history.

Ricoeur returns to discuss Husserl's Cartesian Meditations in his 1990 study of the self and self-awareness, Soi-même comme un autre (Oneself as Another). In this case, his specific interest is in Husserl's version of the Cartesian cogito. He praises Husserl's recognition of the other subject as "the intrinsically first other," ${ }_{s s}$ as well as Husserl's introduction of the distinction between Leib and Körper, which had already featured prominently in Freedom and Nature (1950). However, he thinks Husserl never really could understand the other except as another " $\mathrm{I}$ ". ${ }^{\text {s }}$ These later discussions tend to repeat points Ricoeur had made earlier about Husserl and shows that his views on Husserl did not really change. Ricoeur also says, in Oneself as Another,, that the notion of horizon taken from Husserl has been present in his work from the beginning, and, of course, he also uses the notion of horizon in The Rule of Metaphor.

It is clear that Husserlian phenomenology permeates Ricoeur's oeuvre from start to finish. Ricoeur had an essentially phenomenological approach to the "eidetics" or the conceptual framework of phenomena. The phenomenological reduction (understood both as an eidetic and a transcendental reduction) plays a particularly important role for Ricoeur, since he regularly employs it to bring into focus the essence of a particular phenomenon in its pure possibility without any concern for actuality. He described phenomena (e.g. willing) first in their pure possibility and then later, as in Freedom and Nature, attempts to discuss an "empirics" of the phenomenon. It is undoubtedly also the case that Ricoeur sought always to make his work comprehensive and systematic and his books often suffer to this extent from having to bear the weight of the relatively artificial architectonic that was imposed on the subject matter - hence the distinction between the eidetics, the empiric, the symbolic and the mythic in his volumes on the Philosophy of the Will. In fact, Ricoeur was an essentially dialogical, dialectical and mediational thinker, deeply attuned not just to concepts but to the various kinds of texts in which they were embedded and acutely aware of different voices. Thus his investigation of metaphor

Journal of French and Francophone Philosophy | Revue de la philosophie française et de langue française 
extended from Aristotle through to Max Black, Donald Davidson and contemporary analytic philosophy of language as well as to Heidegger and Derrida. Already in the 1960s, in lectures in the USA, he was comparing the later Husserl with the later Wittgenstein on language, ${ }^{, 1}$ or discussing both Aristotle and Anscombe on voluntary action alongside Husserlian phenomenology. Nevertheless, I believe that Ricoeur's thought is essentially founded in Husserlian phenomenology and cannot be truly understood without it. This is evident in an interview Ricoeur gave in July 1991 speaking of his work and his engagement with analytic philosophy as found in Oneself as Another:

The detour through analytic philosophy is one more detour in a method which rests on detours. Detour/return is the rhythm of my philosophical respiration. But I have always been very sensitive to the force of argumentation in analytic philosophy, which seems to me to accord completely with the great conceptual concerns Husserl had, and which phenomenologists after him did not share.92

It is clear here, in this interview, that the last word is always with Husserl as the most rigorous of conceptual theorists, the very model of the philosophy of reflection.

${ }^{1}$ Maurice Merleau-Ponty, “Le philosophe et son ombre,” in Signes (Paris: Gallimard, 1960), 222-223; trans. R. McCleary, "The Philosopher and His Shadow," Signs (Evanston: Northwestern University Press, 1964) : 176-177.

${ }^{2}$ See Paul Ricoeur, “Intellectual Autobiography,” trans. Kathleen Blamey, in The Philosophy of Paul Ricoeur, Library of Living Philosophers, ed. Lewis E. Hahn (Chicago: Open Court, 1995): 3-53. See also François Dosse, Paul Ricoeur: Les Sens d'une Vie (1913-2005) (Paris: La Découverte, 2008).

${ }^{3}$ See Herman Leo Van Breda, "Le sauvetage de l'héritage husserlien et la fondation des Archives Husserl," in Husserl et la pensée moderne, eds. Herman Leo Van Breda and Jacques Taminiaux (The Hague: Nijhoff, 1959), for the exciting story of the smuggling of the manuscripts.

${ }^{4}$ Ricoeur's earliest publications were on Karl Jaspers and Gabriel Marcel. Paul Ricoeur, Gabriel Marcel et Karl Jaspers. Philosophie du mystère et philosophie du paradoxe (Paris: Le Seuil, 1948) and, with Michel Dufrenne, Karl Jaspers et la philosophie de l'existence (Paris: Le Seuil, 1947), which was written during his internment and was inspired by Jaspers' three-volume Philosophy (published in Berlin in 1932). See Paul Ricoeur, "A Philosophical Journey, From Existentialism to the Philosophy of Language,” Philosophy Today 17, no. $2 / 4$ (Summer 1973): 8896.

${ }^{5}$ Paul Ricoeur, Critique and Conviction, Conversations with François Azouvi and Marc de Launay, trans. Kathleen Blamey (New York: Columbia U. P., 1998), 24. 
${ }^{6}$ E. Husserl, Méditations Cartésiennes, trans. E. Levinas and Gabrielle Peiffer (Paris: Colin, 1931, now Vrin) trans. D. Cairns, Husserl, Cartesian Meditations (Dordrecht: Kluwer, 1993).

7 Edmund Husserl, "Die Frage nach dem Ursprung der Geometrie als intentional-historisches Problem," Revue Internationale de Philosophie, vol. 1 no. 2 (1939) : 203-35. This text was edited by Eugen Fink and published in an issue of the journal in memoriam of Husserl who died the previous year in 1938. It is likely that Fink added the title which translates as "The Origin of Geometry as an Intentional-Historical Problem." In his introductory preface Fink claims that Husserl had offered a regressive inquiry into the foundations of logic in his 1929 Formal and Transcendental Logic, and that now he was turning to a similar analysis of mathematics.

${ }^{8}$ E. Husserl, Die Krisis der europäischen Wissenschaften und die Transzendentale Phänomenologie, ed. Walter Biemel, Husserliana VI (Dordrecht: Springer, 1954), trans. David Carr, The Crisis of European Sciences and Transcendental Phenomenology (Evanston: Northwestern University Press, 1970).

9 E. Levinas, La Théorie de l'intuition dans la phénoménologie de Husserl (Paris: Félix Alcan, 1930), trans. A. Orianne, The Theory of Intuition in Husserl's Phenomenology (Evanston: Northwestern U. P., 1973).

10 See Peter Kemp, "Ricoeur Between Heidegger and Levinas: Original Affinnation Between Ontological Attestation and Ethical Injunction," Philosophy and Social Criticism, vol. 21 (1995). Ricoeur was critical of Heidegger from the beginning, see his "Existence and Hermeneutics," in The Conflict of Interpretations: Essays in Hermeneutics, ed. Don Ihde (Evanston: Northwestem University Press, 1974).

11 Jean-Paul Sartre, The Psychology of Imagination (New York, 1948). Indeed, Ricoeur discusses Sartre's concept of imagining in his Freedom and Nature, 97.

${ }^{12}$ See Paul Ricoeur, "Kant et Husserl," Kant Studien vol. XLVI (1954): 44-67, translated as "Kant and Husserl," in P. Ricoeur, Husserl. An Analysis of His Philosophy (Evanston: Northwestern, 1967): 175-201.

${ }^{13}$ Ricoeur, “Kant and Husserl," 175.

${ }^{14}$ E. Husserl, Ideen zu einer reinen Phänomenologie und phänomenologischen Philosophie. Zweites Buch: Phänomenologische Untersuchungen zur Konstitution, ed. Marly Biemel, Husserliana IV (The Hague: Nijhoff, 1952); trans. R. Rojcewicz and A. Schuwer, Ideas pertaining to a Pure Phenomenology and to a Phenomenological Philosophy, Second Book. Husserl Collected Works III (Dordrecht: Kluwer, 1989).

${ }^{15}$ See P. Ricoeur, "Analyses et problèmes dans "Ideen II" de Husserl," Revue de métaphysique et de morale LVI (Oct-Dec 1951): 357-94; and LVII (Jan-March 1952): 1-16; trans. as "Ideas II: Analyses and Problems," in Husserl. An Analysis of His Phenomenology, 35- 81.

${ }^{16}$ See Paul Ricoeur, Fallible Man, trans. Charles A. Kelbley, revised edition (New York: Fordham University Press, 1986), xliv: “... recourse to a hermeneutics, that is, to rules of deciphering applied to a world of symbols."

${ }^{17}$ Paul Ricoeur, Temps et récit vol. 1 (Paris: Seuil, 1983), vol. 2 (1984), vol. 3 (1985); Time and Narrative, 3 vols, trans. Kathleen Blamey and David Pellauer (Chicago: University of Chicago Press, vol .1, 1984, vol. 2, 1985, vol. 3, 1988).

${ }^{18}$ Roland Dalbiez, La méthode psychanalytique et la doctrine freudienne, 2 vols., avec une préface de Henri Claude (Paris: Desclée de Brouwer, 1936). See Paul Ricoeur, "Mon premier maître en philosophie," in Honneur aux maîtres, ed. Marguerité Léna (Paris: Critérion, 1991): 221-225. 
${ }^{19}$ Paul Ricoeur, De l'interprétation. Essai sur Sigmund Freud (Paris: Le Seuil, 1965); trans. Denis Savage as Freud and Philosophy: An Essay on Interpretation (New Haven: Yale University Press, 1970).

${ }^{20}$ Charles E. Reagan, Paul Ricoeur: His Life and Work (Chicago: The University of Chicago Press, 1996), 8.

${ }^{21}$ Reagan, Paul Ricoeur: His Life and Work, 10.

${ }^{22} \mathrm{E}$. Husserl, Idées directrices pour une phénoménologie, tome I, 1913, trad. De l'allemand par P. Ricoeur (Paris: Gallimard, 1950).

${ }^{23}$ Paul Ricoeur and Michel Dufrenne, Karl Jaspers et la philosophie de l'existence (Paris: Le Seuil, 1947).

${ }^{24}$ Reagan, Paul Ricoeur: His Life and Work, 10.

${ }^{25}$ Reagan, Paul Ricoeur: His Life and Work, 17.

${ }^{26}$ Paul Ricoeur, Philosophie de la volonté. Tome I: Le volontaire et l'involontaire (Paris: Aubier, 1950), trans. Erazim Kohak Freedom and Nature: The Voluntary and the Involuntary (Evanston: Northwestern University Press, 1966). Volume Two appeared in 1960 as Philosophie de la volonté. Tome II: Finitude et culpabilité, 2 volumes (Paris: Aubier, 1960).

${ }^{27}$ Paul Ricoeur, A Key to Husserl's Ideas I, ed. Pol Vandevelde, trans. Bond Harris and Jacqueline Bouchard Spurlock (Milwaukee: Marquette University Press, 1996).

${ }^{28}$ Paul Ricoeur, A l'école de la phénoménologie (Paris: Seuil, 1967). The essays in this volume were translated into English, presented in a different order in P. Ricoeur, Husserl: An Analysis of His Phenomenology, trans. Edward G. Ballard and Lester Embrtee (Evanston: Northwesten, 1967).

${ }^{29}$ See Husserl-Archiv Leuven, Geschichte des Husserl-Archivs History of the Husserl-Archives (Dordrecht: Springer, 2007), 77.

${ }^{30}$ For Ricoeur's years in Strasbourg, see Daniel Frey, ed., La Jeunesse d'une pensée: Paul Ricœur à l'Université de Strasbourg (1948-1956) (Strasbourg: Presses universitaires de Strasbourg, 2016).

${ }^{31}$ P. Ricoeur, "Méthode et tâche d'une phénoménologie de la volonté," in Problèmes actuelles de la phénoménologie, ed. H. L. Van Breda (Paris: Desclée de Brouwer, 1952) : 113-140; translated as P. Ricoeur, "Methods and Tasks of a Phenomenology of the Will," in Husserl: An Analysis of His Phenomenology, 213-233.

${ }^{32}$ Reagan, Paul Ricoeur: His Life and Work, 124.

${ }^{33}$ See L'Homme capable - Autour de Paul Ricœur. Rue Descartes, Hors série (revue du Collège international de philosophie), (Paris: PUF, 2006). Ricoeur is aware of other phenomenological studies of the will, especially Alexander Pfänder's Phenomenology of Willing and Motivation (Evanston: Northwestern University Press, 1967).

${ }^{34}$ Ricoeur, "Methods and Tasks of a Phenomenology of the Will," 215.

${ }^{35}$ Ricoeur, Husserl: An Analysis of His Phenomenology, 217.

${ }^{36}$ Reagan, Paul Ricoeur: His Life and Work, 124.

${ }^{37}$ P. Ricoeur, The Symbolism of Evil, trans. Emerson Buchanan (New York: Harper and Row, 1967).

${ }^{38}$ Ricoeur, Husserl: An Analysis of His Phenomenology, 216.

Journal of French and Francophone Philosophy | Revue de la philosophie française et de langue française Vol XXV, No 1 (2017) | http://www.jffp.org | DOI 10.5195/jffp.2017.800 
${ }^{39}$ Ricoeur, Freud and Philosophy, 30.

${ }^{40}$ Ricoeur, Fallible Man, xliv. Translation modified.

${ }^{41}$ Ricoeur, Freud and Philosophy, 121-22.

${ }^{42}$ Reagan, Paul Ricoeur: His Life and Work, 26.

${ }^{43}$ Reagan, Paul Ricoeur: His Life and Work, 30.

${ }^{44}$ Ricoeur, Freud and Philosophy, 376.

${ }^{45}$ Ricoeur, Freud and Philosophy, 121-122 and 376.

${ }^{46}$ Ricoeur, Freud and Philosophy, 101.

${ }^{47}$ Ricoeur, Freud and Philosophy, 377.

${ }^{48}$ Ricoeur, Freud and Philosophy, 378 and 431.

${ }^{49}$ Ricoeur, Freud and Philosophy, 390.

${ }^{50}$ Paul Ricoeur, La Métaphore vive (Paris: Le Seuil, 1975), trans. Robert Czerny with Kathleen McLaughlin and John Costello, S. J. as The Rule of Metaphor: Multi-Disciplinary Studies in the Creation of Meaning in Language (Toronto: University of Toronto Press, 1978), 373.

${ }^{51}$ P. Ricoeur, L'Homme faillible (Paris, 1960), trans. Charles Kelbley as Fallible Man (Chicago, 1965).

${ }^{52}$ Ricoeur, The Rule of Metaphor, 373.

${ }^{53}$ Ricoeur, Fallible Man, 31.

${ }^{54}$ P. Ricoeur, Husserl: An Analysis of His Phenomenology, 217.

${ }^{55}$ P. Ricoeur, Husserl: An Analysis of His Phenomenology, 7.

${ }^{56}$ Ricoeur makes the comparison explicit. See Ricoeur, Husserl: An Analysis of His Philosophy, 99, when he comments on Husserl's characterization of consciousness's transgressive power, übersich-hinaus-meinen.

${ }^{57}$ Ricoeur, Husserl: An Analysis of His Phenomenology, 26.

${ }^{58}$ P. Ricoeur, Husserl: An Analysis of His Phenomenology, $123 \mathrm{ff}$.

${ }^{59}$ Ricoeur, "A Study of Husserl's Cartesian Meditations I - IV," in Ricoeur, Husserl. An Analysis of His Phenomenology, 83.

${ }^{60}$ Reagan, Paul Ricoeur: His Life and Work, 9.

${ }^{61}$ Ricoeur, Freedom and Nature, 19.

${ }^{62}$ Ricoeur, Husserl. An Analysis of His Phenomenology, 218.

${ }^{63}$ Ricoeur, Husserl. An Analysis of His Phenomenology, 218.

${ }^{64}$ Ricoeur, Freedom and Nature, 66.

${ }^{65}$ Ricoeur, Freedom and Nature, 93.

${ }^{66}$ Ricoeur, Freedom and Nature, 24. 
${ }^{67}$ Ricoeur, Fallible Man, 20. See Henry Isaac Venema, Identifying Selfhood: Imagination, Narrative, and Hermeneutics in the Thought of Paul Ricoeur (Albany, NY: SUNY Press, 2000) for a discussion of the dialectic of the finite and the infinite in human existence.

${ }^{68}$ Ricoeur, Freedom and Nature, 51.

${ }^{69}$ Ricoeur, Freedom and Nature, 61.

${ }^{70}$ Paul Ricoeur, “Phenomenology and Hermeneutics," Nous no. 9 (1975): 85-102.

${ }^{71}$ Ricoeur, Freud and Philosophy, 43.

${ }^{72}$ Ricoeur, "Phenomenology and Hermeneutics," 87.

${ }^{73}$ Ricoeur, "Phenomenology and Hermeneutics," 89.

${ }^{74}$ Paul Ricoeur, Finitude et culpabilité. Tome II. La symbolique du mal (Paris: Aubier, 1960); trans. Emerson Buchanan, The Symbolism of Evil (New York: Harper and Row, 1967).

${ }^{75}$ Ricoeur, Rule of Metaphor, 374.

76 See Don Inde, Hermeneutic Phenomenology: The Philosophy of Paul Ricoeur (Evanston: Northwestern University Press, 1970).

${ }^{77}$ See Paul Ricoeur, Le Conflit des interpretations (Paris, 1969), 7; trans. D. Inde, The Conflict of Interpretations: Essays in Hermeneutics (Evanston: Northwestern University Press, 1974), 3.

${ }^{78}$ Ricoeur, Time and Narrative, vol. 1, 84.

${ }^{79}$ See Richard Kearney, Anatheism: Returning to God After God (New York: Columbia University Press, 2011), Introduction.

${ }^{80}$ P. Ricoeur, "Husserl et le sens de l'histoire," Revue de métaphysique et de morale LIV (1949), pp. 280-316; trans. as "Husserl and the Sense of History," in P. Ricoeur, Husserl. An Analysis of His Phenomenology, 143-174. This was a genuinely groundbreaking article since it discussed then unpublished texts.

${ }^{81} \mathrm{E}$. Husserl, La Crise des sciences européennes et la phénoménologie transcendentale (Paris: Presses Universitaires de France, 1962).

${ }^{82}$ Ricoeur, "Husserl and the Sense of History," in Husserl. An Analysis of His Phenomenology, 144.

${ }^{83}$ Paul Ricoeur, Temps et récit. Tome I: L'intrigue et le récit historique (Paris: Le Seuil, 1983), trans. Kathleen Blamey, Time and Narrative. Volume One (Chicago: The University of Chicago Press, 1984), p. 179.

${ }^{84}$ Paul Ricoeur, Temps et récit. Tome II: La configuration dans le récit de fiction (Paris: Le Seuil, 1984).

${ }^{85}$ P. Ricoeur, Time and Narrative, Volume Three, trans. Kathleen Blamey and David Pellauer (Chicago: University of Chicago Press, 1988), 32.

${ }^{86}$ Ricoeur, Time and Narrative, Volume Three, 23.

${ }^{87}$ Paul Ricoeur, Soi-même comme un autre (Paris: Seuil, 1990), trans. Kathleen Blamey as Oneself as Another (Chicago: The University of Chicago Press, 1992).

${ }^{88}$ Ricoeur, Oneself as Another, 323.

${ }^{89}$ Ricoeur, Oneself as Another, 326.

Journal of French and Francophone Philosophy | Revue de la philosophie française et de langue française Vol XXV, No 1 (2017) | http://www.jffp.org | DOI 10.5195/jffp.2017.800 
${ }^{90}$ Ricoeur, Oneself as Another, 310, n. 12.

91 See the unpublished text of a lecture delivered in 1965 or 1966, "Le dernier Wittgenstein et le dernier Husserl sur le langage," collected on the Fonds Ricoeur website (http://www.fondsricoeur.fr/uploads/medias/articles_pr/ricoeur-le-dernier-wittgenstein-et-ledernier-husserl-1.pdf). A rather different English version appeared as P. Ricoeur, "Husserl and Wittgenstein on Language," in Phenomenology and Existentialism, eds. E. N. Lee \& M. Mandelbaum (Baltimore, The Johns Hopkins University Press, 1967): 207-217.

${ }^{92}$ Reagan, Paul Ricoeur: His Life and Work, 133. 